\title{
Expression of the strA-strB Streptomycin Resistance Genes in Pseudomonas syringae and Xanthomonas campestris and Characterization of IS6100 in X. campestris
}

\author{
GEORGE W. SUNDIN† AND CAROL L. BENDER* \\ Department of Plant Pathology, Oklahoma State University, Stillwater, Oklahoma 74078
}

Received 30 March 1995/Accepted 19 May 1995

\begin{abstract}
Expression of the strA-strB streptomycin resistance $\left(\mathrm{Sm}^{\mathrm{r}}\right.$ ) genes was examined in Pseudomonas syringae pv. syringae and Xanthomonas campestris pv. vesicatoria. The str $A$-str $B$ genes in $P$. syringae and $X$. campestris were encoded on elements closely related to Tn5393 from Erwinia amylovora and designated Tn5393a and Tn5393b, respectively. The putative recombination site (res) and resolvase-repressor (tnpR) genes of Tn5393 from $E$. amylovora, $P$. syringae, and $X$. campestris were identical; however, IS6100 mapped within tnpR in $X$. campestris, and IS1133 was previously located downstream of tnpR in E. amylovora (C.-S. Chiou and A. L. Jones, J. Bacteriol. 175:732-740, 1993). Transcriptional fusions (strA-strB::uidA) indicated that a strong promoter sequence was located within res in Tn5393a. Expression from this promoter sequence was reduced when the tnpR gene was present in a cis position relative to the promoter. In $X$. campestris pv. vesicatoria, analysis of promoter activity with transcriptional fusions indicated that IS6100 increased the expression of strA-strB. Analysis of codon usage patterns and percent $\mathrm{G}+\mathrm{C}$ in the third codon position indicated that IS6100 could have originated in a gram-negative bacterium. The data obtained in the present study help explain differences observed in the levels of $\mathrm{Sm}^{\mathrm{r}}$ expressed by three genera which share common genes for resistance. Furthermore, the widespread dissemination of Tn5393 and derivatives in phytopathogenic prokaryotes confirms the importance of these bacteria as reservoirs of antibiotic resistance in the environment.
\end{abstract}

The aminoglycoside antibiotic streptomycin has been utilized in agriculture since the late 1950 s to control populations of phytopathogenic bacteria. Continued usage of streptomycin, however, has been followed by a reduction in efficacy due to resistance in several important phytopathogens (9). Plasmidencoded streptomycin resistance $\left(\mathrm{Sm}^{\mathrm{r}}\right)$ determinants have been previously cloned and characterized (7, 32, 33, 42). Hybridization analyses indicated that a homologous $\mathrm{Sm}^{\mathrm{r}}$ determinant was present in Erwinia amylovora, Pseudomonas syringae pv. papulans, $P$. syringae pv. syringae, and Xanthomonas campestris pv. vesicatoria strains isolated in North and South America $(7,32,42)$. Subsequently, this $\mathrm{Sm}^{\mathrm{r}}$ determinant was identified as a homolog of the tandem strA-strB aminoglycoside phosphotransferase genes (42) which are also present in clinical bacteria on small broad-host-range plasmids such as pBP1 and RSF1010 (27, 36).

The strA-strB homologs in E. amylovora are encoded by Tn5393, a 6.7-kb transposable element whose complete sequence is known (7). Since previous data indicated that the str $A$-str $B$ genes in $P$. syringae pv. syringae and $X$. campestris pv. vesicatoria were encoded by Tn5393-like elements (40-42), we have designated these Tn5393a and Tn5393b, respectively. Tn5393 is similar to elements of the Tn 3 subgroup of the Tn 3 family and $\operatorname{Tn} 2501$; in these transposons, the $\operatorname{tnp} A$ and $\operatorname{tnpR}$ genes are transcribed divergently from promoters located on opposite DNA strands within a central intergenic region termed res (Fig. 1) $(18,37)$. During the transposition of Tn3, the bifunctional protein (TnpR) resolves cointegrates and re-

* Corresponding author. Phone: (405) 744-9945. Fax: (405) 7447373. Electronic mail address: CBENDER@VMS.UCC.OKSTATE. EDU.

$\dagger$ Present address: Department of Microbiology and Immunology (M/C 790), University of Illinois College of Medicine, Chicago, IL $60612-7344$. presses the transcription of $\operatorname{tnp} A$ and $\operatorname{tnpR}$ by binding to res at three distinct sites $(16,21)$.

Although E. amylovora, $P$. syringae pv. syringae, and $X$. campestris pv. vesicatoria each contained Tn5393, the MICs of streptomycin differed widely among them $(7,32,42)$. Strains of E. amylovora containing strA-strB exhibit MICs of streptomycin of 500 to $1,000 \mu \mathrm{g} / \mathrm{ml}(8)$. A 1.2-kb insertion sequence, IS1133, was detected upstream of strA-strB in E. amylovora, and deletion analysis suggested that a promoter sequence present within IS1133 was responsible for expression of these genes (7). The MIC of streptomycin in $X$. campestris pv. vesicatoria $(250 \mu \mathrm{g} / \mathrm{ml}[41])$ differed from that observed in $P$. syringae pv. syringae $(75 \mu \mathrm{g} / \mathrm{ml}[42])$ and could be caused by disparate regulatory elements or differential expression of $\operatorname{str} A$-str $B$ from the same promoter.

Since little is known about regulatory elements which function in both $P$. syringae and $X$. campestris, the main objective of this study was to analyze the expression of $\operatorname{str} A-s \operatorname{tr} B$ in $P$. syringae pv. syringae and $X$. campestris pv. vesicatoria. In this study, we identified a putative promoter within Tn5393a which was involved in the expression of $s t r A-s t r B$. This promoter was negative regulated by the Tn5393a repressor encoded by tnpR. In $X$. campestris pv. vesicatoria, we found that IS6100, an IS6 family insertion sequence which has been recently detected in a number of diverse gram-negative and gram-positive bacterial genera, is located within tnpR upstream of $\operatorname{str} A$-strB. Our results show that IS6100 increased the expression of $\operatorname{str} A$-str $B$ in $X$. campestris pv. vesicatoria, which further demonstrates the importance of insertion sequences in modulating gene expression.

\section{MATERIALS AND METHODS}

Bacterial strains, plasmids, and media. The bacterial strains and plasmids used in the present study are listed in Table 1. Plasmids were propagated in Escherichia coli DH5 $\alpha$ or HB101 before transfer into P. syringae pv. syringae FF5 


\section{Erwinia amylovora}

\section{4}

\section{$\mathrm{S}$}

Tn5393

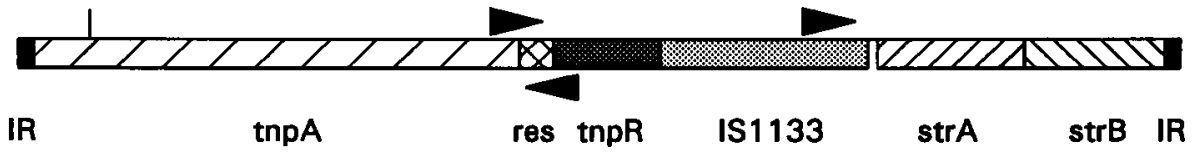

Pseudomonas syringae pv. syringae

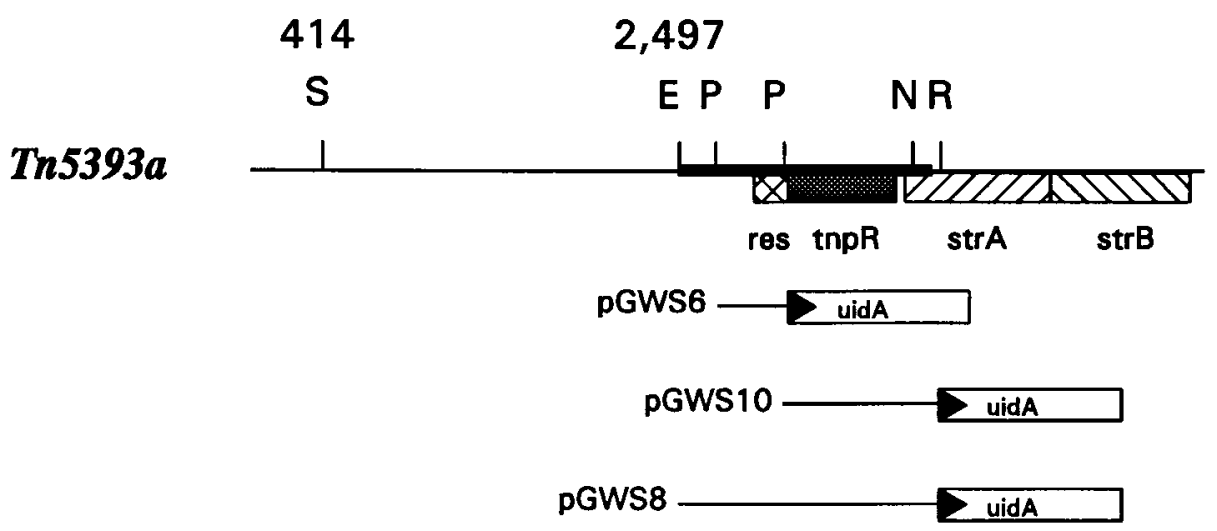

Xanthomonas campestris pv. vesicatoria

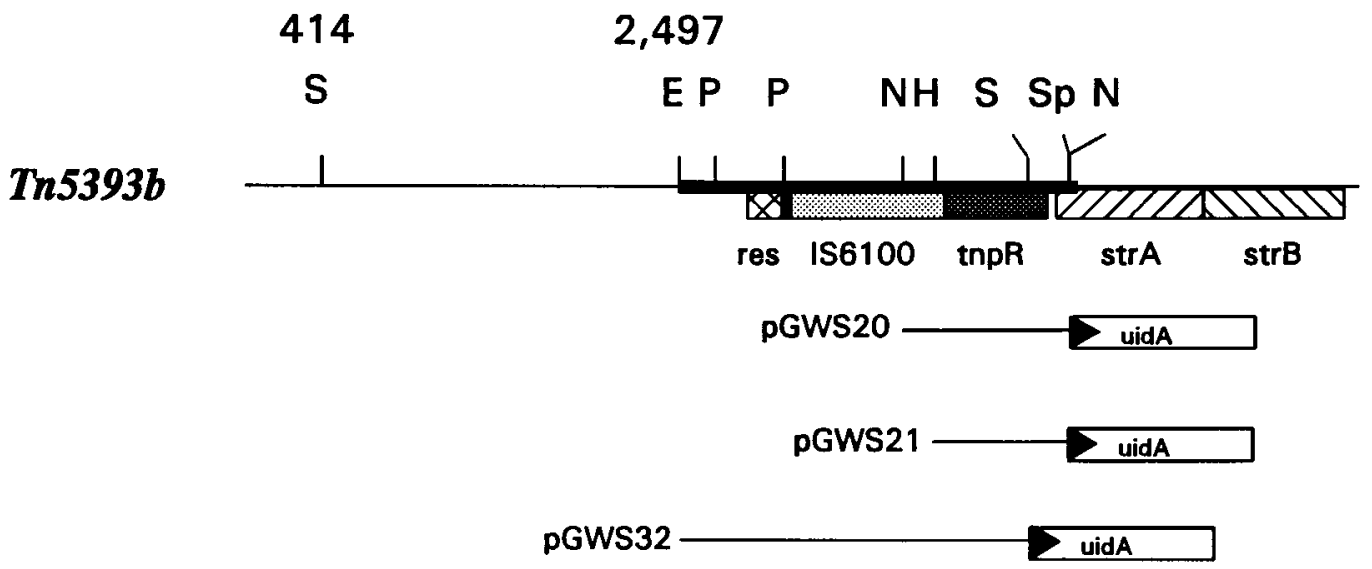

FIG. 1. Physical and functional maps of Tn5393 from E. amylovora, Tn5393a from P. syringae pv. syringae, and Tn5393b from $X$. campestris pv. vesicatoria. The genes and nucleotide assignments are based on the published sequence of Tn5393 from E. amylovora (7): IR, inverted repeat; tnp $A$, transposase; res, recombination site; tnpR, resolvase. str $A$ and str $B$ encode aminoglycoside phosphotransferases. Genes which were characterized in this study or in previous studies (7, 42) are boxed. Regions from $P$. syringae pv. syringae and $X$. campestris pv. vesicatoria which were sequenced in this study are shown as a heavy line. The arrows show the direction of transcription from putative promoters identified in E. amylovora. The transcriptional fusions constructed in this study and their orientation with respect to a promoterless glucuronidase gene, uidA, are indicated (open rectangles and adjacent arrows). Promoter activities are presented in Table 2. Restriction sites utilized in the construction of strA-strB::uidA fusions are indicated. E, H, N, P, R, S, and Sp represent restriction sites for EcoRV, HindIII, NruI, PstI, RsaI, SstI, and Ssp I, respectively.

or X. campestris pv. vesicatoria XV16. E. coli strains were cultured in LB medium (31) at $37^{\circ} \mathrm{C}$. P. syringae and $X$. campestris were grown at $28^{\circ} \mathrm{C}$ in medium B of King et al. (26) and nutrient agar (Difco, Detroit, Mich.), respectively. Following triparental matings, $P$. syringae recipients were selected on mannitol-glutamate medium (24). The antibiotics ampicillin, spectinomycin, streptomycin, and tet- racycline were added to media at concentrations of $40,25,25$, and $12.5 \mu \mathrm{g} / \mathrm{ml}$, respectively.

Cloning and sequencing of regions upstream of $\operatorname{str} A$-strB from $P$. syringae and X. campestris. A cosmid library was constructed from the $68-\mathrm{kb} \mathrm{Cu}^{\mathrm{r}} \mathrm{Sm}^{\mathrm{r}}$ plasmid pPSR1, an indigenous plasmid in P. syringae pv. syringae A2. pPSR1 was purified 
TABLE 1. Bacterial strains and plasmids and their relevant characteristics

\begin{tabular}{|c|c|c|}
\hline Strain or plasmid & Relevant characteristics & Reference \\
\hline \multicolumn{3}{|l|}{ Bacterial strains } \\
\hline \multicolumn{3}{|l|}{ Escherichia coli } \\
\hline DH5 $\alpha$ & & 35 \\
\hline HB101 & & 35 \\
\hline \multicolumn{3}{|c|}{ Pseudomonas syringae pv. syringae } \\
\hline FF5 & $\mathrm{Sm}^{\mathrm{s}}$, no plasmids & 42 \\
\hline A2 & $\mathrm{Cu}^{\mathrm{r}} \mathrm{Sm}^{\mathrm{r}} \operatorname{str} A-s t r B$ on $\mathrm{pPSR} 1$ & 42 \\
\hline \multicolumn{3}{|c|}{ Xanthomonas campestris pv. vesicatoria } \\
\hline BV5-4a & $\mathrm{Sm}^{\mathrm{r}}, \operatorname{str} A-\mathrm{str} B$ on $68-\mathrm{kb}$ plasmid & 32 \\
\hline XV16 & $\mathrm{Sm}^{\mathrm{r}}$ & 15 \\
\hline \multicolumn{3}{|l|}{ Plasmids } \\
\hline pBluescript SK ${ }^{+}$ & $\mathrm{Ap}^{\mathrm{r}}$ cloning vector & Stratagene \\
\hline pLAFR3 & IncP1, $\mathrm{Tc}^{\mathrm{r}}, \mathrm{Mob}^{+}$ & 39 \\
\hline pRG960sd & IncP, $\mathrm{Sm} / \mathrm{Sp}^{\mathrm{r}}, \mathrm{Mob}^{+}$, promoterless uidA; contains Shine-Dalgarno sequence & 46 \\
\hline pRK2013 & $\mathrm{Mob}^{+}, \mathrm{Km}^{\mathrm{r}}$, Tra RK2 & 13 \\
\hline pPSR1 & $68 \mathrm{~kb}, \mathrm{Cu}^{\mathrm{r}} \mathrm{Sm}^{\mathrm{r}}, \operatorname{str} A-\operatorname{str} B$ on $\operatorname{Tn} 5393 \mathrm{a}$ & 42 \\
\hline pPSR1.7 & $\begin{array}{l}\text { pLAFR3 containing a } 22-\mathrm{kb} \text { Sau3A fragment from pPSR1 ligated into the } \\
\text { Bam HI site }\end{array}$ & This study \\
\hline pPSR2 & $190 \mathrm{~kb}, \mathrm{Cu}^{\mathrm{r}} \mathrm{Sm}^{\mathrm{r}}, \operatorname{Tn} 5393 \mathrm{a}$ & 42 \\
\hline pPSR5 & $68 \mathrm{~kb}, \mathrm{Sm}^{\mathrm{r}}, \mathrm{Tn} 5393 \mathrm{a}$ & 42 \\
\hline pSM1 & 3.7-kb PstI of pPSR1 in pBluescript SK+ & 42 \\
\hline pSM7 & 2.8-kb Eco RV of pPSR1.7 in pBluescript SK+ & This study \\
\hline pSM8 & 4.5-kb EcoRI of pPSR1.7 in pBluescript SK+ & This study \\
\hline pGWS2 & 3.7-kb EcoRV of 68-kb Smr plasmid from BV5-4a in pBluescript SK+ & This study \\
\hline pGWS3 & $\begin{array}{l}\text { 3.7-kb EcoRV of } 68-\mathrm{kb} \mathrm{Sm}^{\mathrm{r}} \text { plasmid from BV5-4a in pBluescript SK+ in } \\
\text { opposite orientation }\end{array}$ & This study \\
\hline pGWS4 & 2.2-kb HindIII of pGWS3 in pBluescript SK+ & This study \\
\hline pGWS5 & 0.4-kb PstI of pSM8 in pBluescript SK+ & This study \\
\hline pGWS6 & 0.4-kb PstI of pGWS5 in pRG960sd & This study \\
\hline pGWS8 & 1.45-kb EcoRV-RsaI of pSM7 in pRG960sd & This study \\
\hline pGWS10 & $0.9-\mathrm{kb}$ Pst $\mathrm{I}-\mathrm{R} s \mathrm{I}$ of $\mathrm{pSM} 1$ in $\mathrm{pRG} 960 \mathrm{sd}$ & This study \\
\hline pGWS20 & 0.9-kb NruI of pGWS3 in pRG960sd & This study \\
\hline pGWS21 & 0.6-kb HindIII-SspI of pGWS4 in pRG960sd & This study \\
\hline pGWS32 & 2.0-kb EcoRV-SstI of pGWS2 in pRG960sd & This study \\
\hline
\end{tabular}

on a CsCl-ethidium bromide gradient and partially digested with Sau3A to obtain 20- to $30-\mathrm{kb}$ fragments, which were ligated into pLAFR3 as described previously (39). Cosmids were packaged by using an in vitro packaging kit (Boehringer Mannheim, Indianapolis, Ind.) and transfected into E. coli HB101 as specified by the manufacturer. Plasmid pRK2013 was used to mobilize cosmids into $\mathrm{Sm}^{\mathrm{s}}$ P. syringae pv. syringae FF5; selection of recipients was aided by the intrinsic ampicillin resistance of FF5. A cosmid clone, pPSR1.7, which expressed streptomycin resistance in FF5, and pSM1, which contains strA-strB from pPSR1 on a 3.7-kb PstI fragment (42), were used to generate overlapping subclones for nucleotide sequence analysis.

The indigenous plasmids from $X$. campestris pv. vesicatoria BV5-4a were purified on a CsCl-ethidium bromide gradient, digested with $E c o \mathrm{RV}$, and probed with a 1.5-kb Sst I-EcoRV fragment from RSF1010 which contains the strA-strB genes (36). A 3.7-kb EcoRV fragment which hybridized to this probe was ligated into pBluescript SK + in both orientations to yield pGWS2 and pGWS3, which were further subcloned for DNA sequencing.

Nucleotide sequencing of both DNA strands of all subclones was performed with Sequenase 2.0 (U.S. Biochemical, Cleveland, Ohio) following the instructions of the manufacturer. The location of the SstI site within the transposase (tnpA) gene of $\operatorname{Tn} 5393 \mathrm{a}$ and $\operatorname{Tn} 5393 \mathrm{~b}$ was determined by hybridizing a $0.7-\mathrm{kb}$ SacII fragment from pSM1 to Sst I digests of pPSR1 and to the indigenous plasmids from BV5-4a.

Construction and analysis of $\operatorname{str} A$-strB::uidA fusions. Clones consisting of various DNA fragments of strA-strB in $P$. syringae and $X$. campestris were constructed by ligating fragments into the $S m a \mathrm{I}$ site of the promoter probe vector pRG960sd. In some cases, fragments were first cloned into pBluescript $\mathrm{SK}+$, and blunt-end restriction sites from the pBluescript polylinker were utilized for cloning into the SmaI site of pRG960sd. Clones were introduced into $P$. syringae pv. syringae FF5 and $X$. campestris pv. vesicatoria XV16 via triparental matings (2) and electroporation (15), respectively.

$\beta$-Glucuronidase (GUS) activity in bacteria grown in liquid medium was determined by monitoring the ability of bacterial lysates to catalyze the hydrolysis of 4-methylumbelliferyl glucuronide (22). Prior to processing, cells were grown to late-log phase in medium B of King et al. (26) or nutrient broth containing spectinomycin. Aliquots $(1.5 \mathrm{ml})$ were harvested, suspended in GUS extraction buffer (22), and lysed by sonication. GUS activity, reported as specific activity (units per milligram of protein), was determined fluorometrically as previously described (49). The amount of 4-methylumbelliferone was estimated with a Fluoroscan II spectrofluorometer (ICN Biomedicals, Inc., Costa Mesa, Calif.) which was calibrated with 4-methylumbelliferone standards in $0.2 \mathrm{M} \mathrm{Na}_{2} \mathrm{CO}_{3}$. The protein content in the bacterial lysates was determined by the procedure of Bradford (4). Lysates of $P$. syringae pv. syringae FF5 and $X$. campestris pv. vesicatoria XV16 containing pRG960sd were utilized as negative controls in each experiment. GUS assays for each plasmid construct were performed three times with two replications per experiment.

Analysis of the transcriptional start site located within res in $P$. syringae pv. syringae. Total cellular RNA from 250 -ml overnight cultures of $P$. syringae pv. syringae FF5 containing the $\mathrm{Sm}^{\mathrm{r}}$ plasmid pPSR5 was isolated as described previously (35). Primer extension reactions were conducted in a reaction mixture containing $100 \mathrm{mM}$ Tris- $\mathrm{HCl}(\mathrm{pH} 8.3), 140 \mathrm{mM} \mathrm{KCl}, 50 \mathrm{mM} \mathrm{MgCl}, 10 \mathrm{mM}$ dithiothreitol, $5 \mathrm{mM}$ (each) dATP, dGTP, and dTTP (Boehringer Mannheim), $10 \mu \mathrm{Ci}$ of $\left[\alpha-{ }^{32} \mathrm{P}\right] \mathrm{dCTP}$ (New England Biolabs, Beverly, Mass.), $32 \mathrm{U}$ of RNasin (Promega Corp., Madison, Wis.), and 9.6 U of avian myeloblastosis virus reverse transcriptase (U.S. Biochemical). A synthetic oligonucleotide primer, 5'-TGTC CCGTTCGACACCTG (Oklahoma State University Recombinant DNA/Protein Resource Facility), which corresponded to the complement of the sequence located $10 \mathrm{bp}$ downstream of the translational start for res, was utilized in the reactions. Prior to the addition of the reaction mixture, $20 \mu \mathrm{g}$ of RNA and $20 \mathrm{ng}$ of the oligonucleotide primer were mixed, and the mixture was boiled for $1 \mathrm{~min}$ and chilled quickly on ice. The reaction was incubated at $42^{\circ} \mathrm{C}$ for $30 \mathrm{~min}$, a chase solution containing $0.3 \mu \mathrm{M}$ (each) deoxynucleoside triphosphate was added, and the reaction was incubated for an additional $30 \mathrm{~min}$ at $30^{\circ} \mathrm{C}$. The reaction mixture was then extracted with phenol-chloroform-isoamyl alcohol $(25: 24: 1)$ and precipitated with ethanol. The primer extension reaction mixture was loaded onto an $8 \%$ polyacrylamide sequencing gel adjacent to sequencing reactions of pGWS1 which were generated with the same oligonucleotide primer.

Analysis of codon usage and third-codon-position percent G+C in IS6100. IS6100 elements have recently been detected on nylon-degrading plasmids from Flavobacterium sp., in Pseudomonas sp. adjacent to Tn1696, and as part of the composite transposon Tn610 from Mycobacterium fortuitum (19, 23, 29). We 
were interested in determining if the sequence characteristics of IS6100 reflected an origin in a gram-negative or a gram-positive host. This question was addressed by examining codon usage patterns and percent $\mathrm{G}+\mathrm{C}$ in the third codon position of its putative transposase gene (29). The codon frequencies of 37 coding sequences from $X$. campestris and 16 coding sequences from Mycobacterium spp. were tabulated by using the University of Wisconsin Genetics Computer Group (UWGCG) program CodonFrequency (12). Codon frequency tables of Pseudomonas spp. (6) and Streptomyces spp. (48) were also included in the analysis. The UWGCG program Correspond (17) was used to determine if the codon usage pattern of the putative transposase gene encoded by IS6100 was similar to that of the other gram-negative or gram-positive organisms examined. The Correspond statistic $\mathrm{D}^{2}$ equals the sum over all 64 codons of the equation: $\mathrm{D}^{2}=$ [frequency $_{\text {( }}-$ frequency $\left._{(\text {codon table 2) }}\right]^{2}$. The frequencies compared represent the number of incidents of each individual codon divided by the total number of codons in the table specifying that amino acid or terminator. The $\mathrm{D}^{2}$ statistic decreases as patterns of codon usage become more similar. The percent $\mathrm{G}+\mathrm{C}$ in the third codon position was also calculated from each of the codon frequency tables utilized in this study.

Nucleotide accession numbers. The reported nucleotide sequences were deposited with GenBank/EMBL under accession numbers M77502 (P. syringae pv. syringae) and U20588 (X. campestris pv. vesicatoria).

\section{RESULTS}

Cloning and sequencing of regions upstream of $\operatorname{str} A-s t r B$ in $P$. syringae and $X$. campestris. Subclones from $P$. syringae pv. syringae (Tn5393a) and X. campestris pv. vesicatoria (Tn5393b) containing str $A$-str $B$ and adjacent upstream sequences were subjected to nucleotide sequence analysis. The 1,285 nucleotides of Tn5393a extending from the EcoRV site (nucleotide 2497 in Tn5393 [7]) were identical to a sequence contained in Tn5393. This 1,285-bp sequence in Tn5393a included all of res and tmpR and $60 \mathrm{bp}$ of strA. However, Tn5393a did not contain IS1133 and the flanking sequence TAG, which was presumably generated during the insertion of IS1133 in Tn5393 (Fig. 1). The 1,285-bp sequence in Tn5393a was also present in Tn5393b, except the latter contained an additional 888-bp sequence within tnpR (Fig. 1). A homology search indicated that $880 \mathrm{bp}$ of this sequence was identical to the insertion sequence IS6100 and the additional 8-bp sequence, 5'-AACATATC-3', was duplicated in Tn5393b presumably during insertion of IS6100 within tnpR (8-bp duplications are characteristic of IS6 family elements [14]). We also found the SstI site at position 414 in Tn5393 to be conserved in Tn5393a and Tn5393b (Fig. 1).

Quantification of $\operatorname{str} A$-strB promoter activity in $P$. syringae and $X$. campestris. Expression of $\operatorname{str} A$-strB::uidA transcriptional fusions in $P$. syringae pv. syringae FF5 indicated that a strong promoter sequence was located within the 0.4-kb PstI fragment which contained res in Tn5393a (Fig. 1). GUS activity in FF5(pGWS6), a construct containing the 0.4-kb fragment in pRG960sd, was 100-fold higher than that in FF5(pRG960sd) (Table 2). pGWS10, a clone containing only tnpR and a portion of $\operatorname{str} A$ (Fig. 1), had no detectable promoter activity (Table 2), further indicating that the promoter sequence was located within res in Tn5393a. Repression of GUS activity in the cis configuration was observed in FF5 containing pGWS8, a clone which included the res promoter sequence and tnpR. GUS activity of this construct was approximately fivefold less than that of FF5(pGWS6) (Table 2). tnpR was also tested for repression in trans by monitoring GUS activity in FF5(pGWS6, pPSR2). pPSR2 is an indigenous plasmid in P. syringae pv. syringae which contains Tn5393a. GUS activity in FF5(pGWS6, pPSR2) was only about 1.5-fold lower than that in FF5(pGWS6) (Table 2), possibly because of copy number differences between pGWS6 and pPSR2 (discussed below).

In $X$. campestris pv. vesicatoria XV16(pGWS6), GUS activity was 10-fold higher than in XV16(pRG960sd) (Table 2), indicating that the res promoter isolated from $P$. syringae was active in XV16. However, in XV16 containing pGWS32, a clone
TABLE 2. GUS activity of $\operatorname{str} A$-strB::uidA fusions in $P$. syringae pv. syringae FF5 and $X$. campestris pv. vesicatoria XV16

\begin{tabular}{lcr}
\hline \multicolumn{1}{c}{ Strain and plasmid } & $\begin{array}{c}\text { Mean GUS } \\
\text { activity } \pm \text { SEM } \\
\text { (U/mg of protein) }\end{array}$ & Activity $^{a}$ \\
\hline FF5 & & \\
pGWS6 & $798.4 \pm 100.5$ & 105.1 \\
pGWS6, pPSR2 & $520.4 \pm 43.3$ & 68.5 \\
pGWS8 & $168.7 \pm 20.1$ & 22.2 \\
pGWS10 & $3.3 \pm 2.5$ & \\
pRG960sd & $7.6 \pm 3.7$ & 1.3 \\
pPSR2, pRG960sd & $9.8 \pm 1.3$ & \\
XV16 & & 3.8 \\
pGWS6 & & 2.1 \\
pGWS32 & $125.5 \pm 3.6$ & \\
pGWS20 & $421.3 \pm 8.3$ & \\
pGWS21 & $27.2 \pm 14.2$ & \\
pRG960sd & $1.0 \pm 1.0$ & \\
\hline
\end{tabular}

${ }^{a}$ Expressed relative to that of the strain containing pRG960sd alone.

containing the res sequence and IS6100, GUS activity was threefold higher than that observed with XV16(pGWS6), indicating the role of IS6100 in increasing expression of $\operatorname{str} A$-strB in $X$. campestris (Table 2). GUS activity similar to that of the control was observed for pGWS20 and pGWS21, clones lacking the res and containing sequences from the right outward end of IS6100 (Table 2).

Analysis of the transcriptional start site located within res in $\boldsymbol{P}$. syringae pv. syringae. Since results obtained with $\operatorname{str} A-s t r B:$ : uid $A$ fusions indicated that a strong promoter was located within res in $P$. syringae, we hypothesized that the transcriptional start site for strA-strB was located within res. An 18-bp synthetic oligonucleotide was utilized to synthesize cDNA from total cellular RNA of $P$. syringae pv. syringae FF5 containing pPSR5, a 68-kb Sm${ }^{\mathrm{r}}$ plasmid which harbors Tn5393a. A single primer extension product indicated that transcription was initiated at a guanine residue located within res, $106 \mathrm{bp}$ upstream of the translational start for tnpR (Fig. 2).

Codon usage of the putative transposase gene in IS6100. Codon usage tables compiled from $37 \mathrm{X}$. campestris and 16 Mycobacterium coding sequences and the putative transposase gene of IS6100 were generated with the UWGCG program CodonFrequency (40). Comparative analysis of the codon usage patterns in IS6100 and codon frequency tables of $X$. campestris, Mycobacterium spp., Pseudomonas spp., and Streptomyces spp., using the program Correspond, indicated that the codon usage of the IS6100 transposase was most similar to that of $X$. campestris (Table 3 ). The percent $\mathrm{G}+\mathrm{C}$ in the third codon position of the IS6100 transposase was also most similar to that of $X$. campestris, although it was also similar to that of Mycobacterium spp. (Table 3).

\section{DISCUSSION}

The $\mathrm{Sm}^{\mathrm{r}}$ transposon $\mathrm{Tn} 5393$ and variants reside in many bacteria, including three phytopathogenic genera and many gram-negative bacteria isolated from agricultural habitats where streptomycin is used $(7,38,40,44)$. The sequence identity of tnpR and res from diverse plant pathogens suggests that Tn5393 was recently disseminated. Although the origin of Tn5393 is unknown, a sequence downstream of $s t r B$ in the $\mathrm{Sm}^{\mathrm{r}}$ plasmid RSF1010 is conserved in the right inverted repeat of Tn5393 (IR-5393o) (7, 36), suggesting that this transposon was 


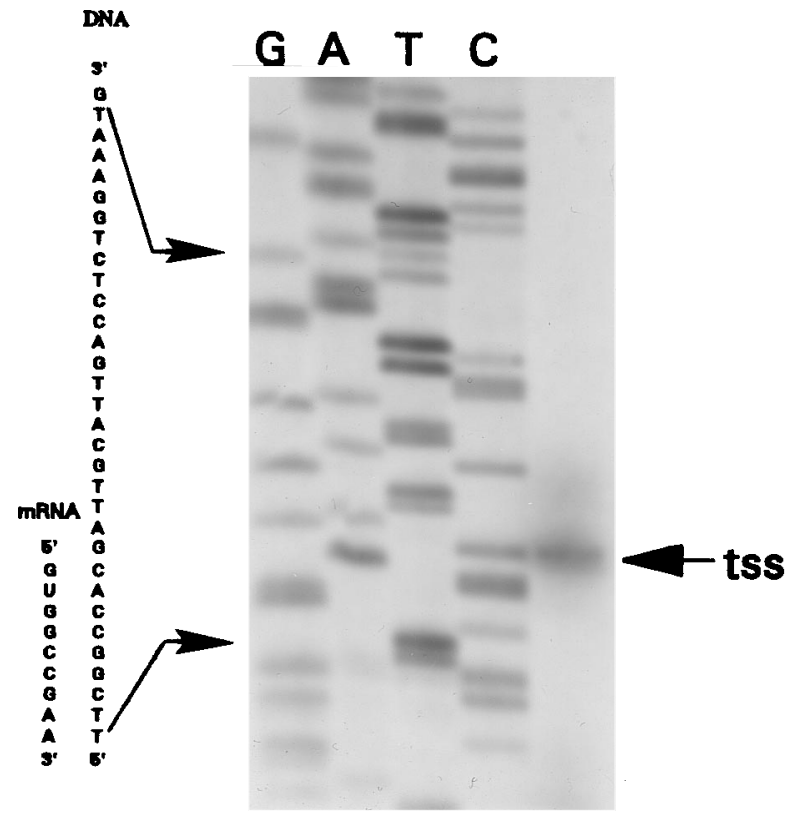

FIG. 2. Transcriptional start site (tss) for $\operatorname{str} A$-str $B$ as determined by primer extension. Autoradiograph shows primer extension product and sequencing reactions; the ${ }^{32} \mathrm{P}$-labeled cDNA product was electrophoresed in parallel with $\mathrm{G} / \mathrm{A} / \mathrm{T} / \mathrm{C}$ sequence reactions generated with the same primer. The DNA sequence and predicted mRNA sequence are shown on the left.

present on other plasmids besides those recently characterized in plant pathogenic bacteria.

Transcriptional fusions generated in the present study indicated that a strong promoter was located in a $0.4-\mathrm{kb}$ Pst I fragment containing essentially all of res (pGWS6, Table 2). Furthermore, GUS activity was markedly reduced when fusion clones included tnpR (pGWS8, Table 2). The function of TnpR as a repressor and its negative effect on the expression of downstream genes was previously shown for Tn3 and the related transposon $\gamma \delta(16,21,34)$. In this study, GUS activity was less affected when tnpR was present in trans on pPSR2 [see FF5(pGWS6, pPSR2), Table 2]. However, GUS activity in FF5(pGWS6, pPSR2) may have been affected by copy number

TABLE 3. Correspond analysis and percent $\mathrm{G}+\mathrm{C}$ in the third codon position for the transposase gene of IS6100 and four bacterial genera

\begin{tabular}{lcc}
\hline \multicolumn{1}{c}{ Organism or gene } & $\begin{array}{c}\text { Correspond }^{\text {analysis }}{ }^{a} \\
\text { IS6100 transposase }\end{array}$ & $\begin{array}{c}\% \mathrm{G}+\mathrm{C} \text { in third } \\
\text { codon position }^{b}\end{array}$ \\
Xanthomonas campestris $^{c}$ & 0.952 & 78.0 \\
Pseudomonas spp. $_{\text {Mycobacterium spp. }}^{c}$ & 1.128 & 80.8 \\
Streptomyces spp. & 1.577 & 73.9 \\
\hline
\end{tabular}

${ }^{a}$ Values presented are the $\mathrm{D}^{2}$ statistic, which was calculated with the UWGCG program Correspond (17). The Correspond analysis compares the pattern of codon usage of the IS6100 putative transposase gene (29) with codon frequency tables for X. campestris (40), Pseudomonas spp. (6), Mycobacterium spp. (40), and Streptomyces spp. (48). The Correspond $\mathrm{D}^{2}$ statistic increases as patterns of codon usage become more dissimilar.

${ }^{b}$ Calculated for the IS6100 putative transposase gene (29) and for the genes utilized to generate the codon frequency tables for $X$. campestris, Pseudomonas spp., Mycobacterium spp., and Streptomyces spp. (6, 40, 48).

${ }^{c}$ Codon usage tables for Xanthomonas and Mycobacterium spp. and the sequences used to compile the tables are available on request.

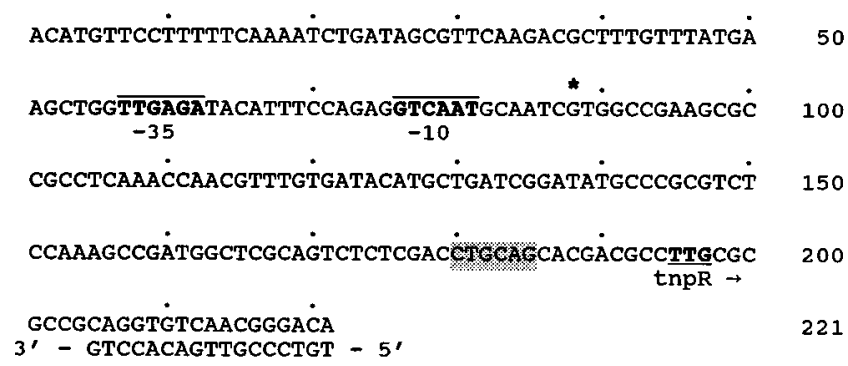

FIG. 3. Nucleotide sequence of the entire recombination site (res) and a portion of tnpR from Tn5393a in P. syringae pv. syringae A2. The transcriptional start site is shown by the asterisk. A putative $\sigma^{70}$ promoter is indicated (overlined bold characters). The putative translation initiation codon (TTG) of tnpR (position 195), as previously determined (7), is shown (underlined bold characters). The PstI site at the $3^{\prime}$ end of res (see Fig. 1) is shaded. The sequence of the oligonucleotide primer utilized in the primer extension reaction is indicated (complement of nucleotides 205 to 221)

differences between pGWS6 and pPSR2 and by the presence of res on pPSR2.

Primer extension analysis indicated that the transcriptional start site for strA-strB in Tn5393a was located within res at a guanine residue $106 \mathrm{bp}$ upstream from the thpR translational start codon. These data imply that the $\operatorname{str} A-\operatorname{str} B$ genes in $P$. syringae are cotranscribed with thpR as an operon. Putative -35 (TTGAGA) and -10 (GTCAAT) sequences, resembling Pseudomonas $\sigma^{70}$ promoters (11), were identified within res seven nucleotides upstream of the transcriptional initiation site (Fig. 3). This sequence differed from a putative $\sigma^{70}$ promoter sequence previously identified within res of Tn5393 (7).

Analysis of transcriptional fusions in $X$. campestris pv. vesicatoria XV16 indicated that expression from the 0.4-kb Pst I fragment in pGWS6 was 10-fold higher than that in the control. Since GUS activity in $P$. syringae pv. syringae FF5 containing pGWS6 was 100 -fold higher than in its control, the relative rates of expression from pGWS6 differed by approximately 10 -fold in $P$. syringae pv. syringae and $X$. campestris $\mathrm{pv}$. vesicatoria. The reduced rate of expression from pGWS6 in $X$. campestris pv. vesicatoria XV16 could be caused by a differential rate of expression from the same promoter sequence in these organisms. Recently, it was determined that the copper resistance determinant from $X$. campestris pv. vesicatoria was similar to the cop operon from $P$. syringae pv. tomato (47). However, these determinants had diverged at the regulatory level, as the cloned $X$. campestris resistance genes were not expressed in $P$. syringae and the cloned cop promoter did not function in $X$. campestris (47). Our data regarding the expression of streptomycin resistance in Pseudomonas and Xanthomonas spp. may also reflect divergence at the regulatory level.

GUS activity in $X$. campestris pv. vesicatoria XV16(pGWS32), a construct containing res, IS6100, and part of tnpR, was 33fold higher than in XV16(pRG960sd). pGWS32 contains an intact copy of IS6100, a member of the IS6 family $(14,29)$. Transcriptional activation of downstream genes by the IS6 family occurs through hybrid promoters consisting of -35 sequences contributed by the right inverted repeat of the IS element and -10 sequences located downstream of the insertion site $(1,5,25,28)$. However, GUS activity was not observed in XV16 containing pGWS20 or pGWS21, both of which contained the right inverted repeat and upstream sequences within IS6100 (Table 2). Thus, another sequence located further within IS6100 functioned as a promoter in X. campestris pv. vesicatoria. The nature of this sequence is unknown since se- 
quences similar to consensus $\sigma^{70}$ promoters (20) were not observed within IS6100.

IS6100 has been detected in Tn610 from M. fortuitum (29), adjacent to Tn1696 in $P$. aeruginosa (19), and on the nylondegrading plasmid pOAD2 in Flavobacterium sp. (23). The presence of identical copies of IS6100 among taxonomically distinct genera indicates that this element has been disseminated both widely and recently among gram-negative and gram-positive bacteria. Although it was once considered unlikely that conjugal transfer of plasmids could occur between gram-negative and gram-positive bacteria, many studies have demonstrated conjugation between these groups in vitro (10, 30 ). Evidence of recent natural transfer events comes from the close nucleotide sequence identity of antibiotic resistance genes identified in gram-positive and gram-negative genera $(5$, $45,50)$. In all of these examples, a natural transfer event from a gram-positive donor to a gram-negative recipient was hypothesized because the nucleotide sequence and codon usage of the genes were most closely related to those of gram-positive genera. However, several lines of evidence suggest that IS6100 was transferred from a gram-negative host to $M$. fortuitum. Data presented by Kato et al. suggest that IS6100 is more closely related to IS6 family elements identified in gram-negative hosts than to those originating from gram-positive bacteria (23). Our analysis of codon usage patterns and percent $\mathrm{G}+\mathrm{C}$ in coding sequences, characteristics which reflect genetic origin $(3,17)$, further supports the origin of IS6100 in a gramnegative host.

The expression of resistance genes encoded by transposons is an important component of their dissemination into new genera. Tn5393a confers $\mathrm{Sm}^{\mathrm{r}}$ to $P$. syringae pv. syringae at 75 $\mu \mathrm{g} / \mathrm{ml}$, a level high enough to provide a selective advantage on plant surfaces sprayed with streptomycin (43). In $X$. campestris pv. vesicatoria, the promoter sequence located within res functions at a low level; however, expression of streptomycin resistance in this organism was increased to $250 \mu \mathrm{g} / \mathrm{ml}$ by the insertion of IS6100 proximal to strA-strB. Similarly, a promoter sequence present in IS1133 was presumed to provide a promoter for the high levels (500 to $1,000 \mu \mathrm{g} / \mathrm{ml}$ ) of streptomycin resistance observed in E. amylovora (7). Thus, Tn5393 is a versatile transposon which is capable of acquiring IS elements to increase the expression of streptomycin resistance in different bacterial genera. The wide dissemination of Tn5393 provides further evidence of the emerging importance of phytopathogenic bacteria as reservoirs of antibiotic resistance determinants in the environment.

\section{ACKNOWLEDGMENTS}

We thank Bob Stall for $X$. campestris pv. vesicatoria BV5-4a.

This work was supported by the Oklahoma Agricultural Experiment Station and National Science Foundation grant EHR-9108771.

\section{REFERENCES}

1. Allmansberger, R., B. Brau, and W. Piepersberg. 1985. Genes for gentamicin-(3)-N-acetyl-transferases III and IV. II. Nucleotide sequences of three AAC(3)-III genes and evolutionary aspects. Mol. Gen. Genet. 198:514-520.

2. Bender, C. L., and D. A. Cooksey. 1987. Molecular cloning of copper resistance genes from Pseudomonas syringae pv. tomato. J. Bacteriol. 169:470474.

3. Bibb, M. J., P. R. Findlay, and M. W. Johnson. 1984. The relationship between base composition and codon usage in bacterial genes and its use for the simple and reliable identification of protein-coding sequences. Gene 30:157-166.

4. Bradford, M. M. 1976. A rapid and sensitive method for the quantitation of microgram quantities of protein utilizing the principle of protein-dye binding. Anal. Biochem. 72:248-254.

5. Brisson-Noel, A., M. Arthur, and P. Courvalin. 1988. Evidence for natural gene transfer from gram-positive cocci to Escherichia coli. J. Bacteriol. 170: $1739-1745$.
6. Cherry, J. M. (Stanford University). 1994. Personal communication.

7. Chiou, C.-S., and A. L. Jones. 1993. Nucleotide sequence analysis of a transposon ( $\mathrm{Tn} 5393$ ) carrying streptomycin resistance genes in Erwinia amylovora and other gram-negative bacteria. J. Bacteriol. 175:732-740.

8. Chiou, C.-S., and A. L. Jones. 1995. Molecular analysis of high-level streptomycin resistance in Erwinia amylovora. Phytopathology 85:324-328.

9. Cooksey, D. A. 1990. Genetics of bactericide resistance in plant pathogenic bacteria. Annu. Rev. Phytopathol. 28:201-219.

10. Courvalin, P. 1994. Transfer of antibiotic resistance genes between grampositive and gram-negative bacteria. Antimicrob. Agents Chemother. 38: 1447-1451.

11. Deretic, V., W. M. Konyecsni, C. D. Mohr, D. W. Martin, and N. S. Hibler. 1989. Common denominators of promoter control in Pseudomonas and other bacteria. Bio/Technology 7:1249-1254.

12. Devereux, J., P. Haberli, and O. Smithies. 1984. A comprehensive set of sequence analysis programs for the VAX. Nucleic Acids Res. 12:387-395.

13. Figurski, D. H., and D. R. Helinski. 1979. Replication of an origin containing derivative of plasmid RK2 dependent on a plasmid function provided in trans. Proc. Natl. Acad. Sci. USA 79:1648-1652.

14. Galas, D. J., and M. Chandler. 1989. Bacterial insertion sequences, p. 109162. In D. E. Berg and M. M. Howe (ed.), Mobile DNA. American Society for Microbiology, Washington, D.C.

15. Garde, S., and C. L. Bender. 1991. DNA probes for detection of copper resistance genes in Xanthomonas campestris pv. vesicatoria. Appl. Environ. Microbiol. 57:2435-2439.

16. Gill, R., F. Heffron, and S. Falkow. 1979. Identification of the transposase and transposon-specific repressor encoded by $\mathrm{Tn} 3$. Nature (London) $\mathbf{2 8 2}$ 797-801.

17. Grantham, R., C. Gautier, M. Guoy, M. Jacobzone, and R. Mercier. 1981. Codon catalog usage is a genome strategy modulated for gene expressivity. Nucleic Acids Res. 9:r43-r74.

18. Grinsted, J., F. de la Cruz, and R. Schmitt. 1990. The Tn21 subgroup of bacterial transposable elements. Plasmid 24:163-189.

19. Hall, R. M., H. J. Brown, D. E. Brookes, and H. W. Stokes. 1994. Integrons found in different locations have identical $5^{\prime}$ ends but variable $3^{\prime}$ ends. J. Bacteriol. 176:6286-6294.

20. Hawley, D. K., and W. R. McClure. 1983. Compilation and analysis of Escherichia coli promoter DNA sequences. Nucleic Acids Res. 11:22372255.

21. Heffron, F., B. J. McCarthy, H. Ohtsubo, and E. Ohtsubo. 1979. DNA sequence analysis of the transposon Tn3: three genes and three sites involved in transposition of Tn3. Cell 18:1153-1163.

22. Jefferson, R. A. 1987. Assaying chimeric genes in plants: the GUS gene fusion system. Plant Mol. Biol. Rep. 5:387-405.

23. Kato, K., K. Ohtsuki, H. Mitsuda, T. Yomo, S. Negoro, and I. Urabe. 1994 Insertion sequence IS6100 on plasmid pOAD2, which degrades nylon oligomers. J. Bacteriol. 176:1197-1200.

24. Keane, P. J., A. Kerr, and P. B. New. 1970. Crown gall of stone fruit. II Identification and nomenclature of Agrobacterium isolates. Aust. J. Biol. Sci. 23:585-595

25. Kim, E., and T. Aoki. 1994. The transposon-like structure of IS26-tetracycline and kanamycin resistance determinant derived from transferable $\mathrm{R}$ plasmid of fish pathogen Pasteurella piscicida. Microbiol. Immunol. 38:31-38.

26. King, E. O., M. K. Ward, and D. E. Raney. 1954. Two simple media for the detection of pyocyanin and fluorescein. J. Lab. Clin. Med. 44:301-307.

27. Korfmann, G., W. Ludtke, U. van Treeck, and B. Wiedemann. 1983. Dissemination of streptomycin and sulfonamide resistance by plasmid pBP1 in Escherichia coli. Eur. J. Clin. Microbiol. 2:463-468.

28. Lee, K.-Y., J. D. Hopkins, and M. Syvanen. 1990. Direct involvement of IS26 in an antibiotic resistance operon. J. Bacteriol. 172:3229-3236.

29. Martin, C., J. Timm, J. Rauzier, R. Gomez-Lus, J. Davies, and B. Gicquel. 1990. Transposition of an antibiotic resistance element in mycobacteria. Nature (London) 345:739-743.

30. Mazodier, P., and J. Davies. 1991. Gene transfer between distantly related bacteria. Annu. Rev. Genet. 25:147-171.

31. Miller, J. H. 1972. Experiments in molecular genetics. Cold Spring Harbor Laboratory, Cold Spring Harbor, N.Y.

32. Minsavage, G. V., B. I. Canteros, and R. E. Stall. 1990. Plasmid-mediated resistance to streptomycin in Xanthomonas campestris pv. vesicatoria. Phytopathology 80:719-723.

33. Norelli, J. L., T. J. Burr, A. M. Lo Cicero, M. T. Gilbert, and B. H. Katz 1991. Homologous streptomycin resistance gene present among diverse gram-negative bacteria in New York State apple orchards. Appl. Environ. Microbiol. 57:486-491.

34. Reed, R. R., G. I. Shibuya, and J. A. Steitz. 1982. Nucleotide sequence of $\gamma \delta$ resolvase gene and demonstration that its gene product acts as a repressor of transcription. Nature (London) 300:381-383.

35. Sambrook, J., E. F. Fritsch, and T. Maniatis. 1989. Molecular cloning: a laboratory manual, 2nd ed. Cold Spring Harbor Laboratory, Cold Spring Harbor, N.Y.

36. Scholz, P., V. Haring, B. Wittmann-Leibold, K. Ashman, M. Bagdasarian, and E. Scherzinger. 1989. Complete nucleotide sequence and gene organi- 
zation of the broad-host-range plasmid RSF1010. Gene 75:271-288.

37. Sherratt, D. 1989. Tn 3 and other related transposable elements, p. 163-184. In D. E. Berg and M. M. Howe (ed.), Mobile DNA. American Society for Microbiology, Washington, D.C.

38. Sobiczewski, P., C.-S. Chiou, and A. L. Jones. 1991. Streptomycin-resistant epiphytic bacteria with homologous DNA for streptomycin resistance in Michigan apple orchards. Plant Dis. 75:1110-1113.

39. Staskawicz, B. J., D. Dahlbeck, N. Keen, and C. Napoli. 1987. Molecular characterization of cloned avirulence genes from race 0 and race 1 of Pseudomonas syringae pv. glycinea. J. Bacteriol. 169:5789-5794.

40. Sundin, G. W. 1994. Ph.D. thesis. Oklahoma State University, Stillwater.

41. Sundin, G. W., and C. L. Bender. Unpublished information.

42. Sundin, G. W., and C. L. Bender. 1993. Ecological and genetic analysis of copper and streptomycin resistance in Pseudomonas syringae pv. syringae. Appl. Environ. Microbiol. 59:1018-1024.

43. Sundin, G. W., and C. L. Bender. 1994. Relative fitness in vitro and in planta of Pseudomonas syringae containing copper and streptomycin resistance plasmids. Can. J. Microbiol. 40:279-285.

44. Sundin, G. W., D. H. Demezas, and C. L. Bender. 1994. Plasmid and genetic diversity of Pseudomonas syringae strains with various exposures to copper and streptomycin bactericides. Appl. Environ. Microbiol. 60:4421-4431.

45. Trieu-Cuot, P., G. Gerbaud, T. Lambert, and P. Courvalin. 1985. In vivo transfer of genetic information between gram-positive and gram-negative bacteria. EMBO J. 4:3583-3587.

46. van den Eede, G., R. Deblaere, K. Goethals, M. van Montagu, and M. Holsters. 1992. Broad host range and promoter selection vectors for bacteria that interact with plants. Mol. Plant Microbe Interact. 5:228-234.

47. Voloudakis, A. E., C. L. Bender, and D. A. Cooksey. 1993. Similarity between copper resistance genes from Xanthomonas campestris and Pseudomonas syringae. Appl. Environ. Microbiol. 59:1627-1634.

48. Wright, F., and M. J. Bibb. 1992. Codon usage in the G+C-rich Streptomyces genome. Gene 113:55-65.

49. Xiao, Y., Y. Lu, S. Heu, and S. W. Hutcheson. 1992. Organization and environmental regulation of the Pseudomonas syringae pv. syringae $61 \mathrm{hrp}$ cluster. J. Bacteriol. 174:1734-1741.

50. Zilhao, R., B. Papadopoulou, and P. Courvalin. 1988. Occurrence of the Campylobacter resistance gene tetO in Enterococcus and Streptococcus spp. Antimicrob. Agents Chemother. 32:1793-1796. 